\title{
Effect of ketorolac administration post bone cavitation surgery on some hematological parameters Raffal A. Omar
}

Department of Surgery and Obstetrics, College of Veterinary Medicine, Baghdad University, Iraq. E-mail: raffal_omar@yahoo.com

Received: 27/4/2016

Accepted: 8/12/2016

\section{Summary}

This study was designed to determine the effect of ketorolac on some hematological parameters post cavitation surgery in domestic rabbits. Ninety-six adult domestic local breed male rabbits were used in this study, weighing $(1.23 \pm 0.33) \mathrm{kg}$. They were divided randomly into two groups in the first one ( $n=48 /$ group) represented control group, while the second one ( $n=48 /$ group) represented the treated group (Ketorolac group). All rabbits in both groups underwent surgical operation (bone cavitation in femur bone) under general anesthesia. In the Ketorolac group, animals were treated by using $30 \mathrm{mg} / \mathrm{kg}$ of Ketorolac directly post-operation and continued daily for 5 days, while in the control group no treatment was given postoperatively. The hematological parameters were recorded included white blood cells count; red blood cells count; hemoglobin; packed cell volume; mean corpuscular hemoglobin and mean corpuscular hemoglobin concentration; mean corpuscular volume and platelets at the period of $(3,5,7,14,21,28,35$, and 42) days post operation were estimated. Results concerning hematological values showed no significant differences in packed cell volume values between control and treated group and within each group, while haemoglobin values showed a significant decrease at period 7 and 14 days between control and treated group. Within the control group the significant decrease was noticed clearly at period of 7 days. Data concerning mean corpuscular hemoglobin values within the control group showed a significant decrease was noticed at 5 day, but within the treated group, there were no significant differences. The mean corpuscular hemoglobin concentration values showed significant decrease ate period $3 ; 5$ and 21 days between control group and treated group respectively. Within control group the significant decrease was noticed obviously at 5 days while within treated group the significant decrease was noticed at 35 days. The mean corpuscular volume values showed significant increase at 3 and 5 days period between control and treated groups. Platelets counts within control group showed significant increase at period of 14 days, within the treated group the significant increase was recorded at 42 days. Red blood cells showed significant decrease between control and treated groups, while within control group, the significant decrease was at 7 days. White blood cells count within treated group showed significant increase recorded at 21 days. Differential White blood cells count concerning Lymphocytes cells within control group the significant increase was recorded at 42 days while the significant decrease was noticed at 21 days, but within treated group the significant increase were recorded at 35 days and significant decrease were noticed at 14 days. Neutrophils counts showed significant decrease at periods 3,14, 28 and 42 days between control and treated groups respectively; while within the control group there was a significant decrease at 3 days, but within treated group the significant decrease was noticed at 42 days. Monocytes cells showed a significant increase at 35 days between control and treated groups, within the control group there was significant increase at 35 days, while within treated group the significant increase recorded at 7 days.

Keywords: Ketorolac, Hematological parameters, Rabbits, Bone cavitation.

\section{Introduction}

Surgical stress causes changes in the composition of blood cells. Ketorolac is believed to have analgesic effects and to reduce the stress response and may therefore improve postoperative outcomes (1). It is surely understood that pain delays recuperation, affects contrarily on a patient's wellbeing, and exasperates the security with its proprietor furthermore the veterinary group. The internationally acknowledged ethic of animal experimentation requires that animal pain and suffering be minimized (2). It is surely understood that bone deformities and 
affection were agonizing, so pain medication is typically a fundamental piece of treatment (3). Not at all like different tissues that repair through the generation of scar tissue, bone recuperates by regeneration new bone (4). To date, proof in the literature proposes that NSAIDS have possibly deleterious effects on bone metabolism and combinations; several examiners demonstrated that admin analgesic agents post operatively could influence bonehealing procedure (5 and 6). The aim of this study was to evaluate the effects of Ketorolac post-operatively on bone healing process based on different parameters, one of these parameters were hematology and blood glucose level.

\section{Materials and Methods}

A total number of 96 adult local breed male rabbits were used in this study with mean weight as $(1.23 \pm 0.33) \quad \mathrm{kg}$ and divided randomly into two equal groups: The control group, while in the second group $(n=48)$ treated with (Ketorolac $30 \mathrm{mg} / \mathrm{kg} \mathrm{B}$.W. for 5 days). They were housed in metal cages $(30 \times 70 \times 60) \mathrm{cm}$ in an air-conditioned room in the animal house of Veterinary Medicine College, University of Baghdad. They had free accesses to water and food, they were exposed to artificial light for 12 hours per day. The animals were left 4 weeks for adaptation with the experimental conditions. Amprolium was used as anti-coccidiosis drug at a dose of $0.6 \mathrm{ml} / \mathrm{L} / 18$ day in drinking water in addition to intramuscular injection of ivermectin at a dose of $0.1 \mathrm{mg} / \mathrm{rabbit}$ and the dose was repeated after 21 days.

The animal was made to fast for six hours and water withdrawn 2 hours before and the site of operation was prepared aseptically. The surgical procedure was done under general anaesthesia by using $17.5 \mathrm{mg} / \mathrm{kg}$ B. Wt. Xylazine and $25 \mathrm{mg} / \mathrm{kg}$ B. Wt. Ketamine in both groups (6). Skin incision extended from the major trochanter to the lateral condyal of the femur was done, then the fascia lata was incised as close as possible to the anterior border of the biceps femoris muscle. The vastus lateralis and biceps femoris muscles were retracted to expose the femur (7). Bone defect (cavitation) was made in the middle of the femoral diaphisis. The bone was drilled to perform a hole into the medullar canal. The defect was performed in the lateral cortex a 2.3 $\mathrm{mm}$ diameter. Drill and a hole were made into the medullar channel. Irrigation by distilled water was done during the induction of bone cavitation (8). Procaine penicillin powder was used as a local antibiotic to the site of bone defect (cavitation area). The wound was closed routinely. Haematological parameters were measured post operation at $(0,3,5,7,14,21$, 28,35 and 42 days) in both experimental groups by using count 60 VET apparatus (GENEX Laboratories -USA), which includes: Haemoglobin $(\mathrm{Hb}) \mathrm{g} / \mathrm{dl}$.; Packed cell volume (PCV)\%; White blood cells (WBCs) cell $/ \mathrm{mm}$; Mean corpuscular hemoglobin $(\mathrm{MCH})$; Mean corpuscular haemoglobin concentration (MCHC), Mean corpuscular volume (MCV) ; Differential counts of W.B.Ss; Red blood cells (RBCs) cell $/ \mathrm{mm}$ and Platelets $/ \mathrm{mm}^{3}$ in addition to blood sugar level $\mathrm{mg} / \mathrm{dl}$. The complete Randomized Design (CRD) within the SAS (2012) program was used to the effect of difference treatments in study traits, and the Least Significant Differences (LSD) test was used to the comparison between means. The ANOVA 2-way was applied to the raw data of those two experiments and $\mathrm{P}<0.05$ was considered to be significant (9).

\section{Results and Discussion}

There was a significant $(\mathrm{P}<0.05)$ increase in treated group at day $7^{\text {th }}(7.16 \pm 1.20)$ in comparison with control group $(4.33 \pm 1.66)$. Within control group the significant $(\mathrm{P}<0.05)$ decrease was noticed in day $7^{\text {th }}$ while within treated group there was non-significant $(\mathrm{P}>0.05)$ changes in R.B.Cs values as shown in (Table, 1).

Table, 1: Shows Red Blood cells count $(\times 10 * 12 / \mathrm{L})$ in control and treated groups.

\begin{tabular}{|c|c|c|c|}
\hline \multirow[t]{2}{*}{ Time (day) } & \multicolumn{2}{|c|}{ Mean \pm SD } & \multirow[t]{2}{*}{ LSD value } \\
\hline & Control & Treated & \\
\hline 0 & $6.58 \pm 1.01$ & $6.58 \pm 1.01$ & 0.00 NS \\
\hline 3 & $7.08 \pm 0.59$ & $6.84 \pm 0.71$ & 0.843 NS \\
\hline 5 & $6.26 \pm 0.41$ & $6.57 \pm 1.21$ & 1.159 NS \\
\hline 7 & $4.33 \pm 1.66$ & $7.16 \pm 1.20$ & $1.873 *$ \\
\hline 14 & $6.88 \pm 0.32$ & $7.23 \pm 0.73$ & 0.732 NS \\
\hline 21 & $7.17 \pm 0.95$ & $6.76 \pm 1.17$ & $1.38 \mathrm{NS}$ \\
\hline 28 & $6.35 \pm 1.65$ & $6.37 \pm 1.17$ & 1.84 NS \\
\hline 35 & $6.52 \pm 1.01$ & $6.51 \pm 1.76$ & $1.85 \mathrm{NS}$ \\
\hline 42 & $6.41 \pm 1.12$ & $6.48 \pm 1.45$ & $1.67 \mathrm{NS}$ \\
\hline LSD value & $2.19 *$ & $1.97 \mathrm{NS}$ & --- \\
\hline $\begin{array}{l}*(\mathrm{P}<0.05) \\
\text { Treated }=\mathrm{ke}\end{array}$ & $\begin{array}{l}\text { IS: Non-sig } \\
\text { lac } 30 \mathrm{mg} /\end{array}$ & $\begin{array}{l}\text { cant. } \\
\text { 3.W. }\end{array}$ & \\
\hline
\end{tabular}


Normally, production and destruction of red cells are kept in balance. The hormone responsible for the regulation of the rate of erythropoiesis is erythropoietin. The fundamental stimulus to erythropoietin production is tissue hypoxia, and so the concentration in plasma is related to the ratio of oxygen supply to oxygen demand. Erythropoietin affects red cell production in four ways which include, more stem cells differentiate to red cell precursors, stages of red cell development are speeded up; transit time out of bone marrow is reduced and (d) immature red cells are released (10). Accordingly (11) found that repeated administration of ketorolac showed no impairment of erythropoietin production and release in response to reduced hematocrit, suggesting that in this instance, prostaglandin inhibition plays a minimal role in erythropoietin production or release. There was a significant increase in $\mathrm{Hb}$ value of treated group at day $7^{\text {th }}$ and 14 day (12.46 $\pm 1.75)$, $(13.11 \pm 1.12)$ in comparison with control group (8.21 \pm 3.63$), \quad(11.88 \pm 0.63)$. While within treated group, the increase of $\mathrm{Hb}$ was no significant $(\mathrm{P}>0.05)$ but within control group, the decrease in $\mathrm{Hb}$ value was significant clearly at 7 days as shown in (Table, 2).

The haemoglobin from a defunct red cell is also broken down. The globin fraction is lysed into its component amino acids which join the general body amino acid pool, either being restructured into new proteins as needed, or being deaminated with the amino residue excreted as urea and the carbohydrate residue entering the fuel metabolism pathways. The haem fraction loses its iron atom, which is not excreted but is recycled into a new haemoglobin molecule. The remaining part of the haem complex becomes bilirubin (10). According to (12 and 13) Ketorolac have antioxidative effect, this anti-oxidative effect could be reduced the oxidative damage of $\mathrm{Hb}$ by the free radicals (14). Induced by surgical operation.

There were non-significant differences between control and treated group in PCV values, also within each group, there were no significant $(\mathrm{P}>0.05)$ changes as shown in (Table, 3). Non- significant changes (decrease or increase) were noticed in $\mathrm{MCH}$ between the control and treated groups. While within the control group there was a significant decrease at day 5, as shown in (Table, 4) However, within treated group the changes were nonsignificant.

Table, 2: Shows Hb concentration (g/dl) in control and ketorolac treated rabbits.

\begin{tabular}{c|ccc}
\hline \multirow{2}{*}{ Time (day) } & \multicolumn{2}{|c}{ Mean \pm SD } & LSD value \\
\cline { 2 - 3 } & Control & Treated & \\
0 & $\mathbf{1 3 . 1 1} \pm \mathbf{1 . 0 7}$ & $\mathbf{1 3 . 1 1} \pm \mathbf{1 . 0 7}$ & $\mathbf{0 . 0 0} \mathbf{~ N S}$ \\
3 & $\mathbf{1 2 . 0 1} \pm \mathbf{0 . 4 6}$ & $\mathbf{1 1 . 9 0} \pm \mathbf{1 . 1 2}$ & $\mathbf{1 . 1 1} \mathbf{~ N S}$ \\
5 & $\mathbf{9 . 2 3} \pm \mathbf{3 . 0 7}$ & $\mathbf{1 1 . 6 5} \pm \mathbf{1 . 6 1}$ & $\mathbf{3 . 1 5} \mathbf{~ N S}$ \\
7 & $\mathbf{8 . 2 1} \pm \mathbf{3 . 6 3}$ & $\mathbf{1 2 . 4 6} \pm \mathbf{1 . 7 5}$ & $\mathbf{3 . 6 7} *$ \\
14 & $\mathbf{1 1 . 8 8} \pm \mathbf{0 . 6 3}$ & $\mathbf{1 3 . 1 1} \pm \mathbf{1 . 1 2}$ & $\mathbf{1 . 1 7} *$ \\
21 & $\mathbf{1 2 . 9 5} \pm \mathbf{1 . 4 4}$ & $\mathbf{1 1 . 8 8} \pm \mathbf{1 . 6 2}$ & $\mathbf{1 . 9 7} \mathbf{~ N S}$ \\
28 & $\mathbf{1 1 . 0 5} \pm \mathbf{3 . 0 9}$ & $\mathbf{1 1 . 6 3} \pm \mathbf{2 . 0 6}$ & $\mathbf{3 . 3 8} \mathbf{~ N S}$ \\
35 & $\mathbf{1 1 . 5 5} \pm \mathbf{1 . 3 6}$ & $\mathbf{1 1 . 5 3} \pm \mathbf{3 . 1 9}$ & $\mathbf{3 . 1 5} \mathbf{~ N S}$ \\
42 & $\mathbf{1 2 . 2 0} \pm \mathbf{1 . 7 5}$ & $\mathbf{1 1 . 4 3} \pm \mathbf{2 . 3 2}$ & $\mathbf{2 . 6 4} \mathbf{~ N S}$ \\
LSD value & $\mathbf{4 . 0 7} *$ & $\mathbf{3 . 2 6} \mathbf{N S}$ & --- \\
$*(\mathrm{P}<0.05)$, & & & \\
NS: Non-significant. & & \\
Treated $=$ ketorolac $30 \mathrm{mg} / \mathrm{kg}$ B.W. & \\
\hline
\end{tabular}

Table, 3: Shows PCV (\%) in control and control and ketorolac treated rabbits..

\begin{tabular}{|c|c|c|c|}
\hline \multirow{2}{*}{$\begin{array}{l}\text { Time } \\
\text { (day) }\end{array}$} & \multicolumn{2}{|c|}{ Mean \pm SD } & \multirow{2}{*}{$\begin{array}{l}\text { LSD } \\
\text { value }\end{array}$} \\
\hline & Control & Treated & \\
\hline 0 & $54.50 \pm 11.72$ & $54.50 \pm 11.72$ & 0.00 NS \\
\hline 3 & $65.16 \pm 5.63$ & $56.50 \pm 11.13$ & $11.34 \mathrm{NS}$ \\
\hline 5 & $66.67 \pm 4.41$ & $64.66 \pm 13.41$ & $12.84 \mathrm{NS}$ \\
\hline 7 & $60.00 \pm 10.35$ & $66.33 \pm 3.44$ & $9.92 \mathrm{NS}$ \\
\hline 14 & $60.50 \pm 9.31$ & $66.16 \pm 6.55$ & $10.35 \mathrm{NS}$ \\
\hline 21 & $70.67 \pm 9.15$ & $64.00 \pm 10.82$ & 12.89 NS \\
\hline 28 & $71.83 \pm 5.15$ & $61.67 \pm 11.32$ & 11.31 NS \\
\hline 35 & $67.00 \pm 7.64$ & $64.00 \pm 7.45$ & 9.71 NS \\
\hline 42 & $64.83 \pm 5.19$ & $69.33 \pm 4.67$ & 6.35 NS \\
\hline LSD value & 19.07 NS & 18.83 NS & -- \\
\hline \multicolumn{4}{|c|}{$\begin{array}{l}\text { NS: Non-significant. } \\
\text { Treated = ketorolac } 30 \text { mg/kg B.W. }\end{array}$} \\
\hline
\end{tabular}

Table, 4: Shows MCH concentration (pg) values in control and ketorolac treated rabbits.

\begin{tabular}{|c|c|c|c|}
\hline \multirow[t]{2}{*}{ Time (day) } & \multicolumn{2}{|c|}{ Mean \pm SD } & \multirow[t]{2}{*}{ LSD value } \\
\hline & Control & Ketorolac & \\
\hline 0 & $20.08 \pm 1.94$ & $20.08 \pm 1.94$ & 0.00 NS \\
\hline 3 & $17.25 \pm 0.86$ & $\mathbf{1 7 . 3 5} \pm \mathbf{0 . 5 0}$ & $0.910 \mathrm{NS}$ \\
\hline 5 & $14.55 \pm 4.22$ & $17.90 \pm 1.62$ & 4.12 NS \\
\hline 7 & $17.63 \pm 0.73$ & $17.56 \pm 0.68$ & 0.917 NS \\
\hline 14 & $17.26 \pm 1.21$ & $18.11 \pm 0.64$ & $1.24 \mathrm{NS}$ \\
\hline 21 & $18.03 \pm 0.65$ & $17.61 \pm 0.86$ & 0.986 NS \\
\hline 28 & $17.62 \pm 0.77$ & $18.28 \pm 1.09$ & $1.218 \mathrm{NS}$ \\
\hline 35 & $17.81 \pm 2.00$ & $17.65 \pm 0.70$ & $1.92 \mathrm{NS}$ \\
\hline 42 & $18.45 \pm 0.45$ & $17.68 \pm 1.08$ & 1.071 NS \\
\hline LSD value & $3.71 *$ & $2.09 \mathrm{NS}$ & --- \\
\hline $\begin{array}{l}*(\mathrm{P}<0.05), \\
\text { NS: Non-sig } \\
\text { Treated }=\text { ket }\end{array}$ & cant. & & \\
\hline
\end{tabular}

A significant decreased at 3, 5 and 21 days period in MCHC were noticed in the control 
group in comparison with the treated group. While within control group, the decrease in MCHC value was a significant clearly at $5^{\text {th }}$ days. But within treated group, the decrease was significant $(\mathrm{P}<0.05)$ mostly at 35 days as shown in (Table, 5).

Table, 5: Shows MCHC concentration (g/dl) in control and ketorolac treated rabbits.

\begin{tabular}{|c|c|c|c|}
\hline \multirow[t]{2}{*}{ Time (day) } & \multicolumn{2}{|c|}{ Mean \pm SD } & \multirow[t]{2}{*}{ LSD value } \\
\hline & Control & Treated & \\
\hline 0 & $24.95 \pm 0.00$ & $24.95 \pm 0.00$ & $0.00 \mathrm{NS}$ \\
\hline 3 & $17.66 \pm 0.85$ & $18.60 \pm 0.31$ & $0.821 *$ \\
\hline 5 & $14.45 \pm 4.31$ & $19.64 \pm 2.89$ & $4.72 *$ \\
\hline 7 & $18.10 \pm 0.72$ & $18.55 \pm 0.16$ & 0.677 NS \\
\hline 14 & $18.05 \pm 1.40$ & $19.73 \pm 1.49$ & $1.86 \mathrm{NS}$ \\
\hline 21 & $19.90 \pm 1.67$ & $18.16 \pm 0.27$ & $1.53 *$ \\
\hline 28 & $17.65 \pm 1.14$ & $18.61 \pm 0.38$ & $1.09 \mathrm{NS}$ \\
\hline 35 & $17.93 \pm 1.82$ & $17.81 \pm 0.68$ & $1.76 \mathrm{NS}$ \\
\hline 42 & $17.85 \pm 0.82$ & $17.98 \pm 0.71$ & 0.99 NS \\
\hline LSD value & $3.42 *$ & $3.59 *$ & --- \\
\hline \multirow{2}{*}{\multicolumn{4}{|c|}{$\begin{array}{l}*(\mathrm{P}<0.05) \\
\text { NS: Non-sig }\end{array}$}} \\
\hline & & & \\
\hline Treated $=$ & & & \\
\hline
\end{tabular}

The result at period 3 and 5 days showed a significant $(\mathrm{P}<0.05)$ increase between control and treated groups concerning $\mathrm{MCV}$. While within the treated group there were significant increase in the period from 35 days, but within control group the significant increase were recorded at 42 days period as shown in (Table, $6)$.

Table, 6: Shows MCV (fL) in control and ketorolac treated rabbits.

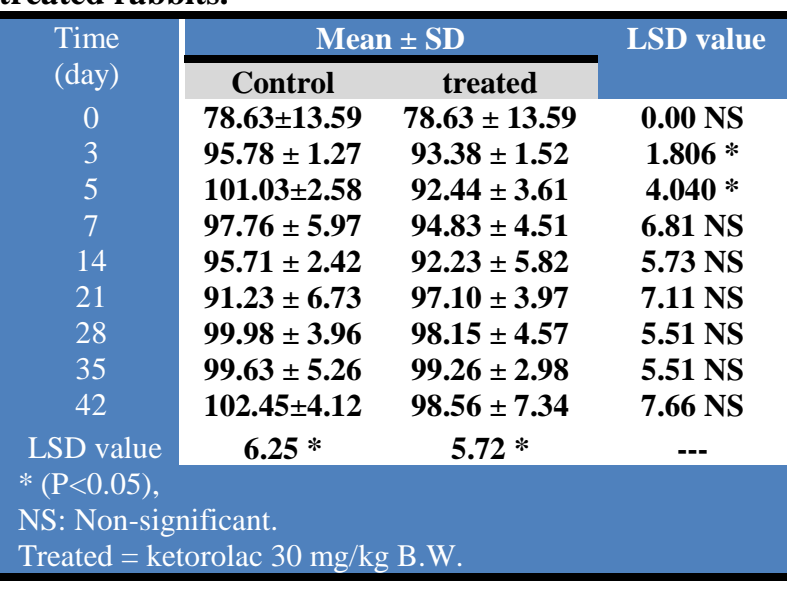

Morphology of the red cells is mean corpuscular volume (MCV) and mean corpuscular hemoglobin concentration (MCHC) values, which are both calculated parameters in veterinary hematology. Young animals tend to have rather smaller red cells than adults. An abnormally high MCHC is not possible as such, there is no such thing as a hyperchromic red cell. When there is an increased demand for red cells (e.g. hemorrhage, oxygen starvation) production is increased firstly by allowing younger forms (reticulocytes, normoblasts) to enter the circulation, and secondly by allowing the maturation stages to merge and skip so that erythropoiesis speeds up.

In platelets there was a significant $(\mathrm{P}<0.05)$ changes in which control group showed a significant increase at day $14 \quad(1060.17 \pm$ 798.70) $\times^{10^{* 9}} / \mathrm{L}$. While within treated group the significant $(\mathrm{P}<0.05)$ increase were noticed at day $42(1442.33 \pm 673.1) \times{ }^{10 * 9} / \mathrm{L}$. as shown in (Table, 7).

A monolayer of endothelial cells lines the intimal surface of blood vessels throughout the circulatory tree, and under normal circumstances, these cells maintain blood fluidity by roviding a thromboresistant surface. Anticoagulant factors of endothelial cells include prostacyclin $\left(\mathrm{PGI}_{2}\right)$, an eicosanoid product of arachidonic acid metabolism, and nitric oxide, a component of endotheliumderived relaxing factor (EDRF). Prostacyclin and nitric oxide maintain blood cells in a quiescent state by inducing vasorelaxation and inhibiting platelets. Prostacyclin stimulates adenylyl cyclase and raises the level of cyclic AMP in vascular smooth muscle cells and platelets. Nitric oxide stimulates guanylyl cyclase and raises levels of cyclic GMP in the same cell types. At a site of vascular injury, thromboresistant properties of endothelial cells are lost or impaired, and thrombogenic subendothelial components of the vessel wall (e.g., collagen) become exposed to blood.

Platelets attach to the damaged vessel wall through a lipid pools by phospholipases (phospholipase $A_{2}$ or the sequential actions of phospholipase $\mathrm{C}$ and diglyceride lipase), which are activated by various extracellular stimuli. Cyclooxygenases then catalyze the oxygenation of free arachidonic acid to cyclic endoperoxide prostaglandin $\mathrm{G}_{2}\left(\mathrm{PGG}_{2}\right)$, which was subsequently converted by hydro peroxidase to $\mathrm{PGH}_{2}$. (In platelets, arachidonic acid is also oxygenated by a 12- lipoxygenase to form 12-hydroperoxy and 12-hydroxy- fatty acids, which have uncertain biologic roles). Subsequently, cells selectively differentiate in 
their metabolism of cyclic endoperoxides to biologically active products (e.g., via thromboxane synthase to thromboxane $\mathrm{A}_{2}$ in platelets, or via prostacyclin synthase to prostacyclin in endothelial cells). Platelet-derived thromboxane $\mathrm{A}_{2}$ and endothelium- derived prostacyclin and nitric oxide have directly opposing actions on platelets and the vessel wall. Platelet-derived thromboxane $\mathrm{A}_{2}$ is a potent platelet activator and vasoconstrictor, and endothelium- derived prostacyclin and nitric acid are platelet inhibitors and vasodilators. The balance of their production represents an important determinant of the state of platelet-vessel wall interactions, blood fluidity and hemostasis (15). Although NSAIDs have potential side effects because of derangement of haemostasis caused by decreased platelet function, but many studies found that ketorolac does not affect the standard platelet aggregation (16). And this could be due to the reversible effects of some NSAIDs in which they inhibit platelet aggregation for a few hours only (17).

Table, 7: Shows Platelets $\left(x^{10^{* 9}} / L\right)$ in control and ketorolac treated rabbits..

\begin{tabular}{|c|c|c|c|}
\hline \multirow{2}{*}{$\begin{array}{l}\text { Time } \\
\text { (day) }\end{array}$} & \multicolumn{2}{|c|}{ Mean \pm SD } & \multirow[t]{2}{*}{ LSD value } \\
\hline & Control & treated & \\
\hline 0 & $294.83 \pm 147.64$ & $294.83 \pm 147.64$ & 0.00 NS \\
\hline 3 & $535.00 \pm 169.22$ & $376.83 \pm 194.47$ & $234.50 \mathrm{NS}$ \\
\hline 5 & $695.50 \pm 200.78$ & $624.67 \pm 114.39$ & 210.21 NS \\
\hline 7 & $931.67 \pm 485.03$ & $446.83 \pm 111.36$ & 452.68 NS \\
\hline 14 & $1060.17 \pm 798.70$ & $1055.00 \pm 548.58$ & 535.30 NS \\
\hline 21 & $381.33 \pm 252.03$ & $923.67 \pm 635.65$ & 222.01 NS \\
\hline 28 & $487.08 \pm 238.82$ & $518.33 \pm 232.76$ & 303.35 NS \\
\hline 35 & $371.33 \pm 286.15$ & $757.33 \pm 395.35$ & 443.94 NS \\
\hline 42 & $707.33 \pm 447.16$ & $1442.33 \pm 673.1$ & 435.14 NS \\
\hline $\begin{array}{l}\text { LSD } \\
\text { value }\end{array}$ & $574.39 *$ & $681.09 *$ & --- \\
\hline
\end{tabular}

Both groups showed no significant changes in W.B.Cs value (increase) when compared between both of them. While within treated group a significant $(\mathrm{P}<0.05)$ increase was noticed at 21days, but within control group there was non-significant $(\mathrm{P}>0.05)$ changes as shown in (Table, 8). Although the increase in glucose level was non-significant between groups and within each one but this increase could be affect on the count of W.B.Cs at the period 0 to 7 days in treated group. It is well known that insulin efficiently induces DNA synthesis in the hematopoietic stem cells (Which are responsible for WBC and thrombocyte production); it exerts regulatory effect on the rate of growth and proliferation of these cells (18). And this increase in glucose level mean that insulin level decrease which deprive the stem cells from these proliferative factors, and causes the decrease in WBC count at this period ( 0 to 7 ) days, also hyperglycemia may result in hyperosmolarity and in glycosylation of leukocyte's membrane proteins, thus decreasing membrane fluidity leading to its break down and cell death according to (19). Since insulin deficiency is reported to cause leukopenia (20), therefore, the decrease in glucose level at the period from 7 to 21 days, may tend to alleviate its symptoms and cause WBC values return back to the normal level.

Table, 8: Shows White Blood cells count $(\times 10 * 9 / \mathrm{L})$ control and ketorolac treated rabbits..

\begin{tabular}{|c|c|c|c|}
\hline \multirow[t]{2}{*}{ Time (day) } & \multicolumn{2}{|c|}{ Mean \pm SD } & \multirow[t]{2}{*}{ LSD value } \\
\hline & Control & Treated & \\
\hline 0 & $9.26 \pm 5.22$ & $9.26 \pm 5.22$ & 0.00 NS \\
\hline 3 & $9.43 \pm 2.10$ & $9.08 \pm 2.15$ & $2.73 \mathrm{NS}$ \\
\hline 5 & $11.16 \pm 2.84$ & $10.65 \pm 2.13$ & $3.23 \mathrm{NS}$ \\
\hline 7 & $10.75 \pm 6.86$ & $7.85 \pm 2.17$ & 6.55 NS \\
\hline 14 & $7.58 \pm 3.09$ & $8.11 \pm 2.60$ & $3.68 \mathrm{NS}$ \\
\hline 21 & $10.11 \pm 4.90$ & $15.18 \pm 7.32$ & 8.02 NS \\
\hline 28 & $9.57 \pm 4.27$ & $9.10 \pm 2.54$ & $4.52 \mathrm{NS}$ \\
\hline 35 & $9.70 \pm 7.00$ & $10.67 \pm 6.81$ & 8.89 NS \\
\hline 42 & $9.67 \pm 4.98$ & $14.43 \pm 5.45$ & $6.72 \mathrm{NS}$ \\
\hline LSD value & $6.84 \mathrm{NS}$ & $6.31 *$ & --- \\
\hline $\begin{array}{l}*(\mathrm{P}<0.05), \\
\text { NS: Non-sig } \\
\text { Treated }=\text { ket }\end{array}$ & nt. & & \\
\hline
\end{tabular}

The result between treated and control groups concerning Lymphocytes (\%) are shown in (Table, 9) and no significant $(\mathrm{P}>0.05)$ changes were noticed between them at the period from 0 time to 42 days, While within treated group there were significant $(\mathrm{P}<0.05)$ increase at the period of 35 days and within control group there were a significant increased obvious at period of 42 days.

The result between treated and Control groups concerning neutrophils are shown in (Table, 10) and a significant changes were noticed between control group at the period 3, 14, 28 and 42 days respectively and treated group at the same periods 3, 14, 28 and 42 days $(42.16 \pm 5.94,36.00 \pm 3.09,49.50 \pm 4.84$ and $33.00 \pm 2.96)$ respectively. While within treated 
group there was a significant $(\mathrm{P}<0.05)$ decrease at period 42 days $(33.00 \pm 2.96)$ and within control group the significant decrease was at the period of 3 days.

Table, 9: Shows Lymphocytes (\%) in control and ketorolac treated rabbits.

\begin{tabular}{|c|c|c|c|}
\hline \multirow[t]{2}{*}{ Time (day) } & \multicolumn{2}{|c|}{ Mean \pm SD } & \multirow[t]{2}{*}{ LSD value } \\
\hline & Control & Treated & \\
\hline 0 & $34.51 \pm 12.70$ & $34.51 \pm 12.70$ & 0.00 NS \\
\hline 3 & $43.10 \pm 4.78$ & $42.81 \pm 6.38$ & $7.25 \mathrm{NS}$ \\
\hline 5 & $35.98 \pm 13.88$ & $35.70 \pm 8.66$ & 14.88 NS \\
\hline 7 & $36.91 \pm 11.26$ & $40.46 \pm 8.55$ & 12.86 NS \\
\hline 14 & $36.41 \pm 8.92$ & $31.53 \pm 5.77$ & $9.67 \mathrm{NS}$ \\
\hline 21 & $29.91 \pm 9.11$ & $41.06 \pm 13.20$ & 14.59 NS \\
\hline 28 & $34.85 \pm 12.37$ & $35.53 \pm 11.41$ & 15.32 NS \\
\hline 35 & $39.95 \pm 14.67$ & $47.60 \pm 7.13$ & 14.84 NS \\
\hline 42 & $45.50 \pm 7.80$ & $43.86 \pm 8.56$ & 10.54 NS \\
\hline LSD value & $13.43 *$ & $14.57 *$ & --- \\
\hline $\begin{array}{l}*(\mathrm{P}<0.05) \\
\text { NS: Non-si } \\
\text { Treated }=\mathrm{k}\end{array}$ & $\begin{array}{l}\text { icant. } \\
\text { olac } 30 \mathrm{mg} /\end{array}$ & & \\
\hline
\end{tabular}

Table, 10: Shows Neutrophils $(\%)$ in control and ketorolac treated rabbits..

\begin{tabular}{c|ccc}
\hline Time (day) & \multicolumn{2}{|c}{ Mean \pm SD } & LSD value \\
\cline { 2 - 3 } & Control & Treated & \\
0 & $\mathbf{5 6 . 0 0} \pm \mathbf{8 . 5 7}$ & $\mathbf{5 6 . 0 0} \pm \mathbf{8 . 5 7}$ & $\mathbf{0 . 0 0 ~ N S}$ \\
3 & $\mathbf{3 4 . 1 6} \pm \mathbf{3 . 9 2}$ & $\mathbf{4 2 . 1 6} \pm \mathbf{5 . 9 4}$ & $\mathbf{6 . 4 7} *$ \\
5 & $\mathbf{5 0 . 8 3} \pm \mathbf{8 . 2 0}$ & $\mathbf{5 3 . 0 0} \pm \mathbf{1 6 . 3 0}$ & $\mathbf{1 6 . 6 0} \mathbf{~ N S}$ \\
7 & $\mathbf{4 6 . 6 6} \pm \mathbf{2 2 . 9 6}$ & $\mathbf{4 2 . 8 3} \pm \mathbf{4 . 2 6}$ & $\mathbf{1 1 . 2 4} \mathbf{~ N S}$ \\
14 & $\mathbf{5 2 . 0 0} \pm \mathbf{1 1 . 2 7}$ & $\mathbf{3 6 . 0 0} \pm \mathbf{3 . 0 9}$ & $\mathbf{1 0 . 6 3} *$ \\
21 & $\mathbf{4 8 . 6 6} \pm \mathbf{8 . 4 7}$ & $\mathbf{4 1 . 0 0} \pm \mathbf{3 . 3 4}$ & $\mathbf{8 . 2 9} \mathbf{~ N S}$ \\
28 & $\mathbf{4 0 . 8 3} \pm \mathbf{4 . 9 5}$ & $\mathbf{4 9 . 5 0} \pm \mathbf{4 . 8 4}$ & $\mathbf{6 . 3 0} *$ \\
35 & $\mathbf{3 6 . 6 7} \pm \mathbf{7 . 1 1}$ & $\mathbf{3 9 . 3 3} \pm \mathbf{2 . 9 4}$ & $\mathbf{7 . 0 1} \mathbf{~ N S}$ \\
42 & $\mathbf{3 5 . 5 0} \pm \mathbf{3 . 7 8}$ & $\mathbf{3 3 . 0 0} \pm \mathbf{2 . 9 6}$ & $\mathbf{4 . 3 7} *$ \\
LSD value & $\mathbf{1 5 . 6 3} *$ & $\mathbf{1 7 . 5 9} *$ & -- \\
* P $<0.05)$, & & & \\
NS: Non-significant. & & \\
Treated $=$ ketorolac $30 \mathrm{mg} / \mathrm{kg}$ B.W. & \\
\hline
\end{tabular}

The result between control and treated groups concerning Monocytes are shown in (Table, 11) and significant changes were noticed between them at the period 35 days While within treated group there was a significant $(\mathrm{P}<0.05)$ increase at period of 7 days, but within control group the significant increased were noticed at 35 days period.

The result recorded non-significant $(\mathrm{P}>0.05)$ changes concerning Eosinophils values between control and treated groups and within each group as shown in (Table, 12). In addition to the effects of ketorolac in pain management, is thought to help maintain immune homeostasis. Leukocytes are the major cellular components of the inflammatory and immune responses, which also include neutrophils, lymphocytes, monocytes, eosinophils, and basophils. Major surgical stress causes lymphopenia with leucocytosis. The increased release of cortisol that accompanies the stress response or the exogenous administration of adrenaline as is done in major surgeries, can also affect leukocyte numbers (1). Although there was an increase in blood glucose level at day $28^{\text {th }}$ in control group in comparison with treated group but it was non-significant $(\mathrm{P}>0.05)$, the same think can be noticed within treated group which recorded a non-significant $(\mathrm{P}>0.05)$ increased at day $7^{\text {th }}$ as shown in (Table, 13).

Table, 11: Shows Monocytes $(\%)$ in control and ketorolac treated rabbits..

\begin{tabular}{c|ccc}
\hline \multirow{2}{*}{ Time (day) } & \multicolumn{2}{|c}{ Mean \pm SD } & LSD value \\
\cline { 2 - 3 } & Control & Treated & \\
0 & $\mathbf{7 . 0 0} \pm \mathbf{1 . 2 6}$ & $\mathbf{7 . 0 0} \pm \mathbf{1 . 2 6}$ & $\mathbf{0 . 0 0 ~ N S}$ \\
3 & $\mathbf{8 . 1 6} \pm \mathbf{1 . 3 2}$ & $\mathbf{9 . 5 0} \pm \mathbf{1 . 5 1}$ & $\mathbf{1 . 8 3} \mathbf{N S}$ \\
5 & $\mathbf{6 . 6 7} \pm \mathbf{1 . 9 6}$ & $\mathbf{8 . 0 0} \pm \mathbf{1 . 4 1}$ & $\mathbf{2 . 2 0} \mathbf{N S}$ \\
7 & $\mathbf{7 . 6 7} \pm \mathbf{3 . 4 4}$ & $\mathbf{1 1 . 5 0} \pm \mathbf{2 . 5 8}$ & $\mathbf{3 . 9 1} \mathbf{N S}$ \\
14 & $\mathbf{5 . 5 0} \pm \mathbf{2 . 4 2}$ & $\mathbf{6 . 3 3} \pm \mathbf{0 . 8 1}$ & $\mathbf{2 . 3 3} \mathbf{N S}$ \\
21 & $\mathbf{9 . 0 0} \pm \mathbf{3 . 4 6}$ & $\mathbf{6 . 6 6} \pm \mathbf{1 . 2 1}$ & $\mathbf{3 . 3 4} \mathbf{N S}$ \\
28 & $\mathbf{9 . 0 0} \pm \mathbf{2 . 1 9}$ & $\mathbf{7 . 8 3} \pm \mathbf{1 . 7 2}$ & $\mathbf{2 . 5 3} \mathbf{N S}$ \\
35 & $\mathbf{1 0 . 0 0} \pm \mathbf{0 . 8 9}$ & $\mathbf{7 . 5 0} \pm \mathbf{1 . 3 7}$ & $\mathbf{1 . 4 9} *$ \\
42 & $\mathbf{9 . 3 3} \pm \mathbf{1 . 0 3}$ & $\mathbf{1 0 . 5 0} \pm \mathbf{1 . 0 4}$ & $\mathbf{1 . 3 4} \mathbf{N S}$ \\
LSD value & $\mathbf{3 . 5 8} *$ & $\mathbf{3 . 3 9} *$ & -- \\
* P $<0.05)$, & & & \\
NS: Non-significant. & & \\
Treated = ketorolac $30 \mathrm{mg} / \mathrm{kg}$ B.W. &
\end{tabular}

Table, 12: Shows Eosinophils $(\%)$ in control and ketorolac treated rabbits..

\begin{tabular}{|c|c|c|c|}
\hline \multirow{2}{*}{ Time (day) } & \multicolumn{2}{|c|}{ Mean \pm SD } & \multirow[t]{2}{*}{ LSD value } \\
\hline & Control & treated & \\
\hline 0 & $0.00 \pm 0.00$ & $0.00 \pm 0.00$ & 0.00 NS \\
\hline 3 & $0.333 \pm 0.034$ & $\mathbf{0 . 5 0 0} \pm \mathbf{0 . 0 8 3}$ & 1.06 NS \\
\hline 5 & $0.00 \pm 0.00$ & $\mathbf{0 . 5 0 0} \pm \mathbf{0 . 0 8 3}$ & 0.76 NS \\
\hline 7 & $0.00 \pm 0.00$ & $0.166 \pm 0.040$ & 0.371 NS \\
\hline 14 & $0.166 \pm 0.040$ & $\mathbf{0 . 3 3 3} \pm \mathbf{0 . 0 5 1}$ & 0.598 NS \\
\hline 21 & $0.166 \pm 0.040$ & $0.666 \pm 0.13$ & $1.010 \mathrm{NS}$ \\
\hline 28 & $0.166 \pm 0.040$ & $\mathbf{0 . 5 0 0} \pm \mathbf{0 . 0 8 3}$ & 0.846 NS \\
\hline 35 & $0.333 \pm 0.051$ & $\mathbf{0 . 5 0 0} \pm \mathbf{0 . 0 8 3}$ & 0.894 NS \\
\hline 42 & $0.166 \pm 0.040$ & $0.333 \pm 0.051$ & $0.830 \mathrm{NS}$ \\
\hline LSD value & 0.333 NS & 0.500 NS & --- \\
\hline $\begin{array}{l}\text { NS: Non-sig } \\
\text { Treated = ke }\end{array}$ & cant. & & \\
\hline
\end{tabular}

Generally development of new drugs that could be target the skeleton, the glucose metabolism, and the adipose tissue are certain to be considered a future perspective. Glucose considered as one of the most important substance for all cells in which it is considered as a fuel resource and the most important organ affected by glucose level is the brain in which any disturbance in this main nutrient will not lead to achieve its function 
normally (21 and 22). And it is well known that the majority of circulating glucose comes from the diet; in the fasting state, gluconeogenesis and glycogenolysis maintain glucose concentrations. Although there was an increase in blood glucose level at day $28^{\text {th }}$ in control group $(167.33 \pm 50.08)$ in comparison with treated group $(136.17 \pm 26.97)$ but it was non-significant $(\mathrm{P}>0.05)$, the same think can be noticed within treated group which recorded a non-significant $(\mathrm{P}>0.05)$ increased at day $7^{\text {th }}(152.00 \pm 31.11)$ as shown in (Table, 4-8). Since Insulin plays an important role in glucose regulation by promoting glucose uptake in adipose tissue and muscle and by suppressing gluconeogenesis in liver. Insulin has been demonstrated to be an osteogenic hormone (23).

Table, 13: Shows Blood sugar (mg/dl) in control and treated groups

\begin{tabular}{|c|c|c|c|}
\hline \multirow{2}{*}{$\begin{array}{l}\text { Time } \\
\text { (day) }\end{array}$} & \multicolumn{2}{|c|}{ Mean \pm SD } & \multirow[t]{2}{*}{ LSD value } \\
\hline & Control & treated & \\
\hline 0 & $119.00 \pm 14.17$ & $119.00 \pm 14.17$ & 0.00 NS \\
\hline 3 & $146.16 \pm 33.72$ & $133.83 \pm 20.86$ & 36.07 NS \\
\hline 5 & $140.50 \pm 11.43$ & $141.33 \pm 17.39$ & 18.93 NS \\
\hline 7 & $147.17 \pm 6.04$ & $152.00 \pm 31.11$ & 28.83 NS \\
\hline 14 & $141.83 \pm 15.26$ & $136.33 \pm 21.24$ & 23.79 NS \\
\hline 21 & $148.17 \pm 51.67$ & $121.50 \pm 18.39$ & 49.89 NS \\
\hline 28 & $167.33 \pm 50.08$ & $136.17 \pm 26.97$ & 51.74 NS \\
\hline 35 & $132.33 \pm 20.48$ & $147.17 \pm 26.58$ & 25.99 NS \\
\hline 42 & $131.83 \pm 6.86$ & $143.33 \pm 41.50$ & $38.24 \mathrm{NS}$ \\
\hline $\begin{array}{l}\text { LSD } \\
\text { value }\end{array}$ & 59.87 NS & $48.95 \mathrm{NS}$ & -- \\
\hline $\begin{array}{l}\text { NS: I } \\
\text { Treat }\end{array}$ & $\begin{array}{l}\text { nificant. } \\
\text { torolac } 3\end{array}$ & & \\
\hline
\end{tabular}

It is well known that mesenchymal cells are affected directly by glucose level especially uncontrolled levels in which any increase in blood glucose will lead to formation of adipose tissue instead of callus formation, so this increase in blood sugar dose not affect on mesenchymal cells which employed to the site of injury and form a protective, rigid cartilaginous structure called a callus (24). Liver glycogen is considered as the best marker of assessing anti hyperglycemic activity of any drug (25). Therefore, previous results suggested that one possible mechanism by which dill bring about is the anti hyperglycemic action which is due to inhibition of hepatic glycogen degradation (26). Naturally controlling glucose levels, dill can actually imitate insulin, through fighting the problem of insulin resistance of the tissue and increased sensitivity of insulin receptors , as well as $\beta$-cell function (27).

Although the increase in blood glucose (hyperglycemia) was non significant between the two groups and within each one but this increase may lead to impaired renal function with inadequate excretion of waste products like creatinine and urea leading to their elevation. This speculation is consistent with (28) who explained that too much sugar in the blood can lead to diverge the renal function parameters from the ranges and causes serious kidney problems (29).

\section{References}

1. Hong, J.Y. (2005). The Effect of Preoperative Ketorolac on WBC Response and Pain in Laparoscopic Surgery for Endometriosis Yonsei Medical J., 46(6):812-817.

2. Fenwick, J.; Gamble, J.; Creedy, D.; Buist, A.; Turkstra, E.; Sneddon, A.; Scuffham, P.; Ryding, E.; Jarrett, V. and Toohill, J. (2014) Study protocol for reducing childbirth fear: a midwife-led psycho-education intervention. BMC Pregnancy Childbirth 2014., 13: Published online October 20th, 2014 doi:10.1186/1471-2393-13-190

3. Shaffran, N. (2008). Pain management: The veterinary technician's perspective. Vet. Clin. North Am. Small Anim. Pract., 38(6):14151428.

4. Puzas, J.E.; O’Keefe, R.J.; Schwarz, E.M.; Zhang, X. (2003) Pharmacologic modulators of fracture healing: the role of cyclo -oxygenase inhibition. J. Musculoskeletal Neuronal Interactions. 3(4):308-312.

5. Herbenick, M. A.; Sprott, D.; Stills, H. and Lawless, M. (2008). Effects of a Cyclooxygenase 2 Inhibitor on Fracture Healing in a Rat Model. Am. J. Orthop., 37(7):133-137.

6. Omar, R. A. (2009). Efficiency of some Analgesics mixed with General Anaesthesia and their Influence on Fracture Healing in Rabbits; Ministry of Higher Education \& Scientific Research University of Baghdad, College of Veterinary Medicine. Pp:62-63.

7. Archibald, J. and Blakely, C. L. (1974). Preoperative Preparation. In Archibald J (ed): Canine Surgery, $2^{\text {nd }}$ ed. Santa Barbara, Animal Veterinary Publications. 
8. Ohashi, H.; Therin, M.; Meunier, A. and Christel, P. (1994). The effect of drilling parameters on bone. J. Materials Sci., Materials in Med., 5(4):232-236.

9. SAS. (2012). Statistical Analysis System, User's Guide. Statistical. Version $9.1^{\text {th }}$ ed. SAS. Inst. Inc. Cary. N.C. USA.

10. Keer, M. G. (2001). Veterinary laboratory medicine: Clinical biochemistry and hematology (Chapter 1), $2^{\text {nd }}$ Ed. Blackwell Science Ltd. Pp:4- 10.

11. Hoff, K. K.; Zawada, E.T.; Alavi, F. K.; Leyse, J. W., and Santella, R. N. (1994). Effects of ketorolac tromethamine on erythropoietin levels in Sprague Dawley rats. Int. J. Artificial Organs. 17(12):629-634.

12. Lee, S. Y.; Suh, J. K.; Choi, J. H.; Jeon, W. J. and Cheong, M.A. (2010). Effect of ketorolac and diclofenac on the impairment of endothelium-dependent relaxation induced by reactive oxygen species in rabbit abdominal aorta. Korean J. Anesthesiol., 59(3):196-202.

13. Mahmood, M. Y.; Mohssin, A. E.; Sura B. K.; Enaam, H. B. (2009). Frequency distribution of hemoglobin variant and abo blood groups among thalassemia patients from ibn-al-baladi pediatric hospital in baghdad/Iraq, World J. Pharm. Pharmaceut. Sci., 4(11):31-39.

14. Zou, C.G.; Agar, N.S. and Jones, G. L. (2001). Oxidative insult in sheep red blood cells induced by t-butyl hydroperoxide: The roles of glutathione and glutathione peroxidase. Free Radical Research, 34(1):4556.

15. Schafer, A. I. (1995). Effects of nonsteroidal antiinflammatory drugs on platelet function and systemic hemostasis. J. Clin. Pharmacol., 35:209-219.

16. Dordoni, P.L.; Ventura, M.D.; Stefanelli, A.; Iannace, E.; Paparella, P.; Rocca, B. and Accorra, F. (1995). Effect of ketorolac, ketoprofen and nefopam on platelet function. Anaesthesia, 49:1046-1049.

17. Tarkkila, P. and Saarnivaara, L. (1999). Ketoprofen, diclofenac or ketorolac for pain after tonsillectomy in adults? British Journal of Anaesthesia. 82(1):56-60.

18. Valentinis, B.; Navarro, M.; Zanocco, M.T.; Edmonds, P. and Reiss, K. (2000). Insulin receptor substrate-1, P7056K and cell size in transformation and differentiation of hematopoietic cells. Biol. Chem., 275:25412545.

19. Paulina, S.; Maria, A.O. and Zulecia, B.F. (1997). Aminoguanidine and the prevention of Leukocyte dysfunction in diabetes mellitus. A direct vital microscopic study. B. J. Pharmaco., 122:894-898.

20. Jeffrey, A. M.; Paul, J.C.; Daniel, G.H.; Robert, J. and Mayer, M.B. (2003). Impact of Diabetes Mellitus on outcomes in patients with colon cancer. J. Clin. Cology., 21(3): 433-440.

21. Brown, S. (2015). Diet In: Information pack. Mid west bird and exotic animal hospital. Pp:1.

22. Choi, I.Y.; Lee, S.P.; Kim, S.G. and Gruetter R. (2001). In Vivo measurements of brain glucose transport using the reversible Michaelis-Menten model and simultaneous measurements of cerebral blood flow changes during hypoglycemia. J. Cerebral Blood Flow and Metabolism. 21:653-663.

23. Faienza, M.F.; Luce, V.; Ventura, A.; Colaianni, G.; Colucci, S.; Cavallo, L.; Grano, M. and Brunetti, G. (2015). Skeleton and Glucose Metabolism: A bone-pancreas loop. Int. J. Endocrinol. Volume 2015, Article ID 758148, 7 pages.

24. Coleman, C. (2010). Diabetic bone fracture repair. www.reddstar.eu. Pp:1-2.

25. Ahmed, O.M.; Mahmoud, A.M.; AbdelMoneim, A. and Ashour, M.B. (2012). Antidiabetic effects of hesperidin and naringin in type 2 diabetic rats. Diabetologia Croatica 41:53-67.

26. Li, G.; Connolly, C.K. and Marsh, D.R. (2006). Association of cell proliferation and cell death events during fracture healing. J. Bone Joint Surg. [Br.], 58(1):3.

27. Kavishankar, G.B.; Lakshmimidevi, N.; Mahadeva Murthy, S.; Prakash, H.S. and Niranjana, S.R. (2011). Diabetes and medicinal plants. Int. J. Pharm. Biomed. Sci., 2:65-80.

28. Sharma, A.; Hirulkar, N.B.; Wadel, P. and Das, P. (2011). Influence of hyperglycemia on renal function parameters in patients with Diabetes Mellitus. Int. J. Pharm. Biol. Arch., 2(2):734-739.

29. Sharma, P.; Senthilkumar, R.D.; Brahmachari, V.; Sundaramoorthy, E.; Mahajan, A.; Sharma A. and Sengupta, S. 
(2006). Mining literature for a comprehensive pathway analysis: a case study for relative of homocysteine related genes for genetic and epigenetic studies. Lipids and Health Disease. 5(1):1186-1476.

\section{تأثئير إعطاء عقار الكيتورولاك بعد عملية إحداث تثثيب العظم في بعض المعاييز الدموية في الأرانب

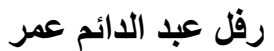

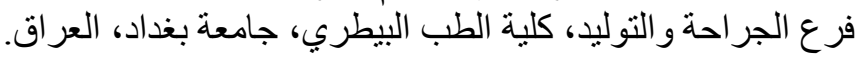

E-mail: raffal_omar@yahoo.com

الخخلاصة

صُُمِمت هذه الدر اسة لمعرفة مدى تأثير عقار الكينورو لاك في التئام العظام في الأر انب المحلية. وقد استُعملت في هذه التجربة

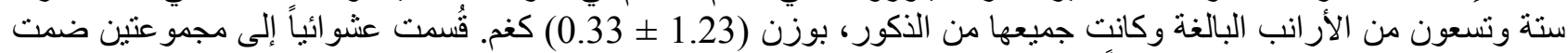

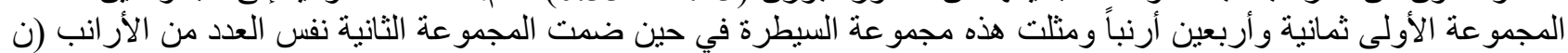

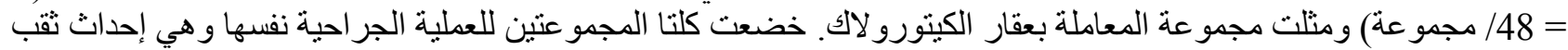

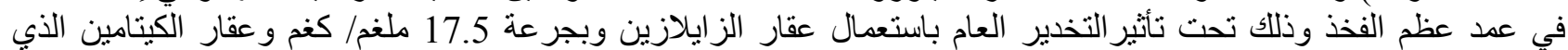

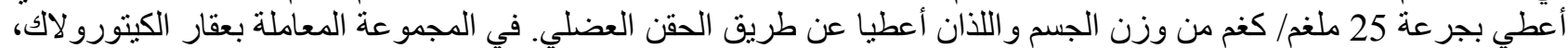

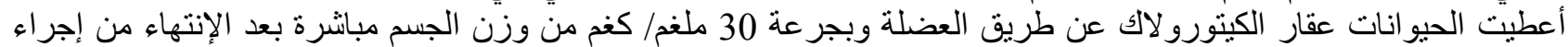

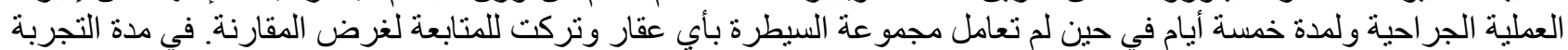

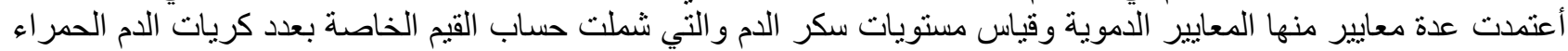

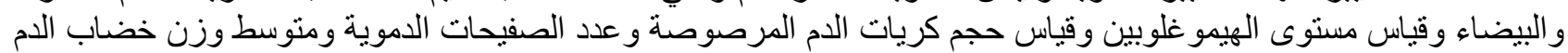

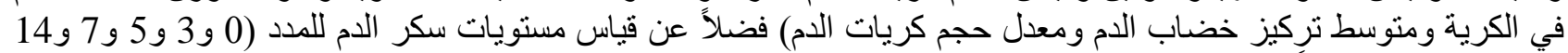

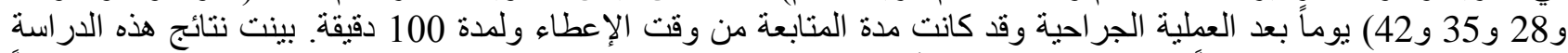

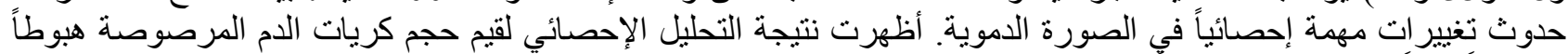

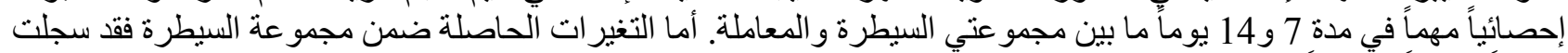

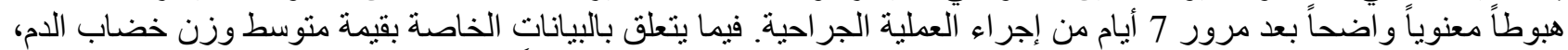

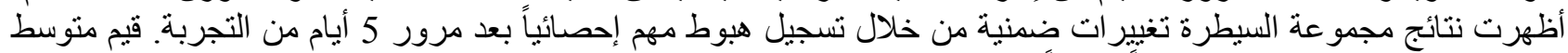

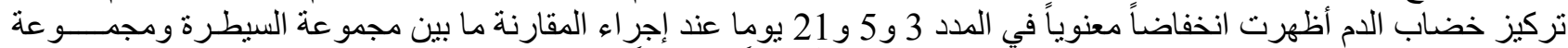

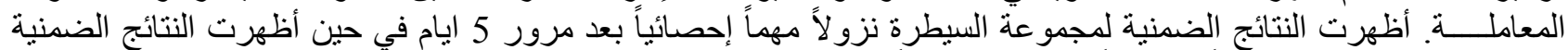

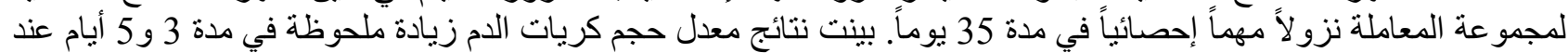

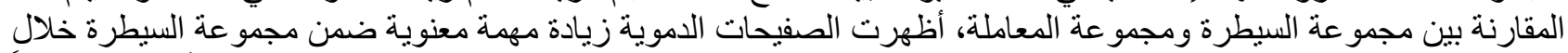

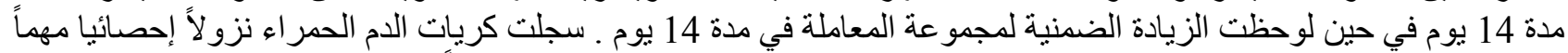

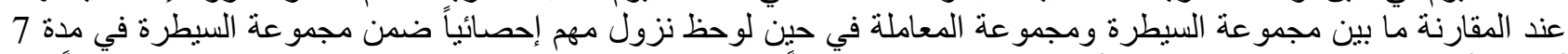

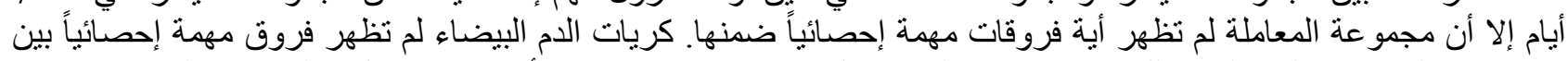

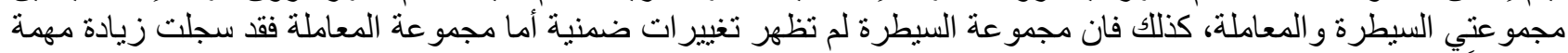

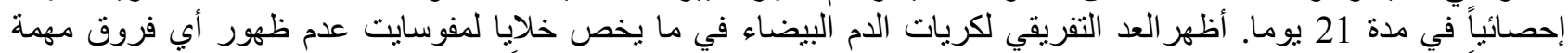

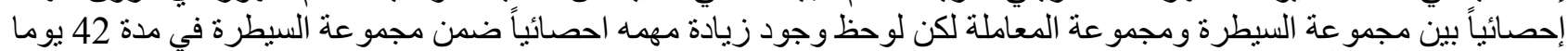

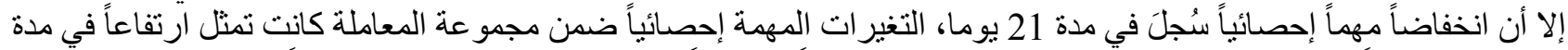

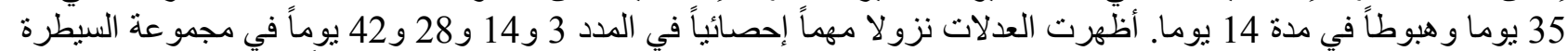

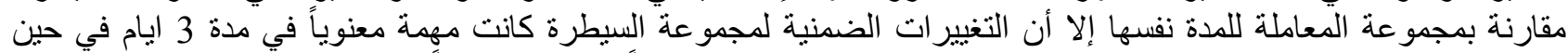

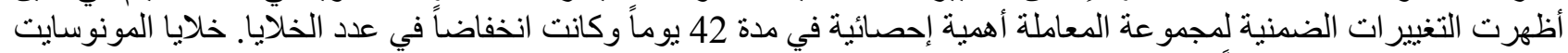

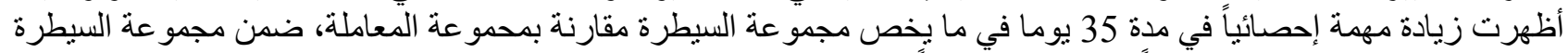

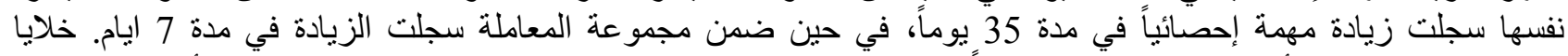

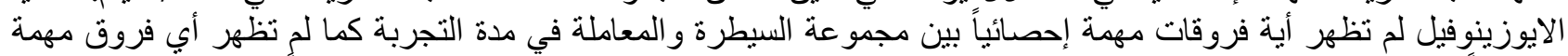

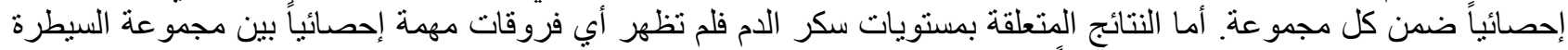

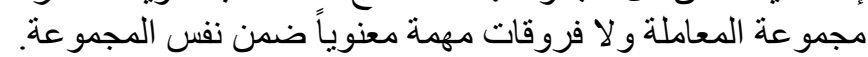

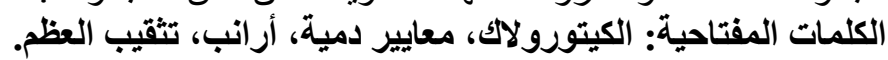

